\title{
Pesticide residues in bee pollen - validation of the gas chromatography- mass spectrometry multiresidual method and a survey of bee pollens from Slovenia
}

\author{
Helena BAŠA ČESNIK ${ }^{1^{*}}$
}

Received August 11, 2020; accepted April 09, 2021. Delo je prispelo 11. avgusta 2020, sprejeto 9. aprila 2021.

Pesticide residues in bee pollen - validation of the gas chromatography-mass spectrometry multiresidual method and a survey of bee pollens from Slovenia

Abstract: A new analytical method for determining environmental pesticide residues in pollen was introduced and validated. The extraction was conducted using acetonitrile, the clean-up using Supelclean Ultra 2400 solid phase extraction cartridges, which contain Grapsphere, anion exchanger C18 and zirconia-based sorbent, and the determination was conducted using gas chromatography coupled with mass spectrometry. The method was applied in practice. A total of 49 active substances (pesticides) were sought in 30 bee pollen samples gathered from Slovenian beekeepers from all 12 statistical regions of Slovenia. The fungicide azoxystrobin was the only active substance found and was found only in one sample with a concentration of $<0.05 \mathrm{mg} \mathrm{kg}^{-1}$. The active substances sought were not detected in $96.7 \%$ of the samples analysed. The risk assessment revealed that the analysed pollen samples do not represent an unacceptable risk for consumers. The results were compared with those from the literature and the outcome was that bee pollen from Slovenia contained a lower number of active substances at mainly lower contents as compared pollen from some other European countries.

Key words: bee pollen; GC-MS; pesticide residues; multiresidual method
Ostanki fitofarmacevtskih sredstev v cvetnem prahu - validacija multirezidualne metode s plinsko kromatografijo sklopljeno $\mathrm{z}$ masno spektrometrijo in preiskava cvetnega prahu iz Slovenije

Izvleček: Uvedli in validirali smo novo analizno metodo za določanje ostankov fitofarmacevtskih sredstev iz okolja. Ekstrakcijo smo izvedli $\mathrm{z}$ acetonitrilom, čiščenje z Supelclean Ultra 2400 koloncami za ekstrakcijo na trdni fazi, ki vsebujejo Grapsphere, anionski izmenjevalnik, C18 in sorbent na osnovi cirkonija, in določitev s plinsko kromatografijo sklopljeno z masno spektrometrijo. Metodo smo uporabili v praksi. V 30 vzorcih cvetnega prahu slovenskih čebelarjev iz vseh 12 statističnih regij Slovenije smo določali skupno 49 aktivnih spojin (pesticidov). Edina najdena aktivna snov je bil fungicid azoksistrobin in sicer le v enem vzorcu, pri koncentraciji $<0,05$ $\mathrm{mg} \mathrm{kg}^{-1}$ Iskanih aktivnih snovi nismo detektirali v 96,7 \% analiziranih vzorcev. $Z$ oceno tveganja smo ugotovili, da analizirani vzorci cvetnega prahu ne predstavljajo tveganja za potrošnika. Rezultate smo primerjali z literaturnimi podatki in ugotovili, da je cvetni prah v Sloveniji vseboval manjše število aktivnih spojin pri v glavnem nižjih vsebnostih fitofarmacevtskih ostankov kot cvetni prah iz nekaterih Evropskih dtžav.

Ključne besede: cvetni prah; GC-MS; ostanki fitofarmacevtskih sredstev; multirezidualna metoda

$1^{*}$ Agricultural Institute of Slovenia, Hacquetova ulica 17, SI-1000 Ljubljana, Slovenia, PhD.

e-mail: helena.basa@kis.si, corresponding author 


\section{INTRODUCTION}

Bee pollen is a dietary supplement. It contains carbohydrates (mainly fructose, glucose and sucrose (13-55 $\%)$, proteins (10-40\%), lipids (1-13\%), and crude fibre (0.3-20\%)), minerals (mainly potassium, phosphorus, calcium, magnesium, zinc, manganese, iron and copper (2-6\%)), vitamins (0.005-5.6 $\left.\mathrm{mg} \mathrm{kg}^{-1}\right)$, and polyphenols (0.69-213.2 $\mathrm{mg} \mathrm{GAE} \mathrm{g}^{-1}$ ) (Thakur and Nanda, 2020). Bee pollen has antioxidant activity, antimicrobial activity, anti-inflammatory activity, anticarcinogenic activity, cardioprotective effects, hepatoprotective effects, antiallergic activity and it boosts the immune system (Li et al., 2018). A diet supplemented with bee pollen strengthens muscles and improves the physical health of humans (Salles et al., 2014). Bee pollen also benefits those undertaking strenuous mental/physical work (Nakajima et al., 2009).

Honeybees fly up to $4.8 \mathrm{~km}$ from their apiary (Eckert, 1933) to collect pollen. When hives are located near agricultural fields, plants treated with plant protection products (PPP) are a possible source of contamination for bee pollen (Tosi et al., 2018). Honeybees may come into contact with PPP residues through the nectar, pollen or plant leaves of treated plants, or through air, soil and water where PPPs have drifted (Crenna et al., 2020).

Bee pollen is usually harvested by means of a trap fixed at the entrance of beehives (Thakur and Nanda, 2020). This type of pollen is called corbicular pollen. Some beekeepers also collect pollen from hives deposited in combs by bees. This type of pollen is called beebread.

Numerous analytical methods have been developed to analyse PPP residues in pollen. The more recent ones are based on the QuEChERS method, which has been introduced to analyse a wide range of PPP residues in fruit and vegetables (Anastassiades et al., 2003, Lehotay, 2007). In this method, acetonitrile is used as an organic solvent for the extraction. The advantage of acetonitrile is that it minimizes the co-extraction of lipids and proteins by precipitating the proteins (Wang et al., 2012) and limiting the lipid solubility (Lozano et al., 2014). This makes acetonitrile a suitable solvent for extracting PPP residues from pollen. In some cases (Tosi et al., 2018; Wiest et al., 2011), n-hexane was added to remove fatty acids and fatty acid esters.

The clean-up in the original QuEChERS method was conducted using primary secondary amine (PSA) sorbent and C18 (Anastassiades et al., 2003; Lehotay, 2007). In the case of pollen some authors used either PSA (Cabrera de Oliveria, 2016; Kasiotis et al., 2014), PSA and C18 sorbent (Mullin et al., 2010), PSA, C18 and graphitized carbon black (GCB) sorbent (David et al., 2016), or PSA, C18 and zirconia-based sorbents such as Z-Sep, which consists of a mixture of $\mathrm{C} 18$ and silica coated with zirconium dioxide sorbents (Hakme et al., 2017, Vázquez et al., 2015). In our laboratory we used Supelclean Ultra 2400 solid phase extraction (SPE) cartridges, which contain Grapsphere (graphitized spherical carbon), PSA, $\mathrm{C} 18$ and Z-Sep. PSA retains acidic interferences such as fatty acids. Grapsphere removes planar molecules such as pigments and at the same time enables better recovery of planar pesticides than GCB. The bottom layer of the cartridge contains Z-Sep, which removes oily residues and provides additional retention of some pigments (Stenerson, 2018). C18 retains lipids (Lehotay,2007). Thus, these SPE cartridges combine all the common clean-up procedures from the literature.

Determination of PPP residues can be performed using gas chromatography coupled with mass spectrometry (GC-MS) (Li et al.; 2015; Mullin et al.,2010; Raimets et al., 2020), GC coupled with tandem mass spectrometry (GC-MS/MS) (Cabrera de Oliveria, 2016), GC coupled with time-of flight mass spectrometry (GC-TOF) (Hakme et al., 2017), and/or liquid chromatography coupled with tandem mass spectrometry (LC-MS/MS) (David et al., 2016; Kasiotis et al., 2014; Raimets et al., 2020). Multiresidual methods are fit-for-purpose when their limits of quantification are lower or equal to the Maximum Residue Limits (MRLs) established for pollen in Regulation (EC) 396/2005. When the MRLs in this Regulation are set at the LOQ determined by the analytical method (this LOQ was gathered by different laboratories), an ${ }^{*}$ is added to mark this fact. Many pesticides have an MRL and LOQ of $0.05 \mathrm{mg} \mathrm{kg}^{-1}$, meaning that GC-MS is still suitable despite its smaller sensitivity than tandem mass detectors.

Numerous authors have analysed pesticide residues in pollen. García-Valcárcel et al. (2019) analysed 10 active substances in pollen samples in Spain. Vázquez et al. (2015) analysed 253 active substances in pollen samples in Spain. Hakme et al. (2017) tested pollen samples from Spain for 100 active substances. Wiest et al. (2011) introduced a method for determining 80 active substances in French pollen. Tosi et al. (2018) analysed 66 active substances in Italian pollen. Kasiotis et al. (2014) analysed 115 active substances in Greek pollen. Raimets et al. (2020) analysed 47 active substances in Estonian pollen. David et al. (2016) analysed 20 active substances in pollen from the United Kingdom. Many of active substances sought in these studies were introduced in our study as well. Our selection of active substances was based on both those authorised for use in Slovenia and those not authorised for use in Slovenia, the latter to cover misuse of PPP. Of those selected, $59 \%$ were acaricides and/or insecticides, which may be the main reason for the death of bees.

The purpose of this paper is to present the multire- 
sidual GC-MS method introduced for identifying 49 active substances in pollen using acetonitrile as the extraction solvent and Supelclean Ultra 2400 SPE cartridges for the clean-up. The validation parameters are summarised, as well as the practical use of the method on 30 samples of bee pollen gathered from Slovenian beekeepers. The contents of pesticide residues were compared with those from the literature. Finally, a risk assessment for consumers was conducted.

\section{MATERIAL AND METHODS}

\subsection{MATERIALS}

\subsubsection{Chemicals}

The certified standards were supplied by Dr. Ehrenstorfer (Augsburg, Germany). The acetonitrile HPLCgrade (used for the extraction procedure) and acetone HPLC-grade (used for preparation of standards) were supplied by J.T.Baker (Deventer, Netherlands). All other chemicals used were supplied by Sigma-Aldrich (Steinheim, Germany). The water used was MilliQ deionised water. The Ultra $24003 \mathrm{ml} \mathrm{SPE}$ columns were supplied by Supelco (Bellefonte, USA).

\subsubsection{Preparation of the solutions}

Stock solutions in acetone of individual active substances were prepared with the concentrations of $625 \mu \mathrm{g}$ pesticide $\mathrm{ml}^{-1}$. From 49 stock solutions, two mixed solutions of all 49 active substances were prepared: one with a concentration of $5 \mu \mathrm{g} \mathrm{ml}^{-1}$ and the second at the LOQ of active substances. All solutions used to determine the linearity and the LOQs and to perform calibration during sample analysis were prepared from a mixed solution of $5 \mu \mathrm{g} \mathrm{ml}^{-1}$ with proper dilutions. For other validation parameters, a mixed solution with a concentration at the LOQ was used.

\subsection{EXTRACTION PROCEDURE}

The samples were analysed within a maximum period of 27 days after arrival at the laboratory. During that time, they were stored at $-20^{\circ} \mathrm{C}$.

To $10 \mathrm{~g}$ of pollen in the beaker, $50 \mathrm{ml}$ of acetonitrile was added. The mixture was homogenised for 2 minutes with a mixer. The mixture was left for 30 minutes so that the sediment settled on the bottom of the beaker. The liquid part was transferred to a $50 \mathrm{ml}$ centrifuge tube and centrifuged for 10 minutes at $7000 \mathrm{rpm}$. The supernatant was filtered through $15 \mathrm{~g}$ anhydrous $\mathrm{Na}_{2} \mathrm{SO}_{4}$ and black strip filter paper into a $100 \mathrm{ml}$ Soxhlet flask. Then $30 \mathrm{ml}$ of acetonitrile was added to the sediment in the beaker. The mixture was homogenised for 2 minutes with a mixer and transferred to a $50 \mathrm{ml}$ centrifuge tube. Centrifugation followed for 10 minutes at $7000 \mathrm{rpm}$. This supernatant was combined with the first one after it was filtered through $15 \mathrm{~g}$ of anhydrous $\mathrm{Na}_{2} \mathrm{SO}_{4}$ and black strip filter paper into a $100 \mathrm{ml}$ Soxhlet flask. The $\mathrm{Na}_{2} \mathrm{SO}_{4}$ was rinsed with $15 \mathrm{ml}$ of acetonitrile. Then acetonitrile in Soxhlet flask was evaporated to approximately $2 \mathrm{ml}$ on a rotavapor and dried with nitrogen flow. The dry eluate was dissolved in $1 \mathrm{ml}$ of acetonitrile using ultrasound. The extract was transferred onto a column of Ultra $24003 \mathrm{ml}$, preconditioned with $3 \mathrm{ml}$ of acetonitrile. The SPE column was rinsed with $16 \mathrm{ml}$ of acetonitrile. The flow rate was 3-4 $\mathrm{ml} \mathrm{min}^{-1}$ under vacuum. The whole eluate (partly taken from the SPE column after the sample was applied to the SPE column and partly eluate created during rinsing of the SPE column) was combined in a beaker. The content of the beaker was transferred to a $100 \mathrm{ml}$ Soxhlet flask. The beaker was rinsed twice with $5 \mathrm{~mL}$ of acetonitrile and the content was transferred to the Soxhlet flask. The acetonitrile was then evaporated to approximately 2 $\mathrm{ml}$ on a rotavapor and dried with nitrogen flow. The dry eluate was dissolved in $1 \mathrm{ml}$ of acetone using ultrasound in order to prepare a sample. For matrix match standards, $1 \mathrm{ml}$ of the working solutions with proper concentrations was added and dissolved using ultrasound.

\section{3. DETERMINATION}

The samples were analysed using a gas chromatograph (Agilent Technologies 7890A, Shanghai, China) equipped with a Gerstel MPS2 multipurpose sampler (Gerstel, Mülheim an der Ruhr, Germany) and a HP-5 MS UI column (Agilent Technologies, $30 \mathrm{~m}, 0.25 \mathrm{~mm}$ i.d., $0.25 \mu \mathrm{m}$ film thickness) with a constant flow of helium at $1.2 \mathrm{ml} \mathrm{min}^{-1}$. The GC oven was programmed as follows: $55^{\circ} \mathrm{C}$ for $2 \mathrm{~min}$, from $55^{\circ} \mathrm{C}$ to $130^{\circ} \mathrm{C}$ at $25^{\circ} \mathrm{C}$ $\min ^{-1}$, held at $130^{\circ} \mathrm{C}$ for $1 \mathrm{~min}$, from $130^{\circ} \mathrm{C}$ to $180^{\circ} \mathrm{C}$ at $5^{\circ} \mathrm{C} \mathrm{min}-1$, held at $180^{\circ} \mathrm{C}$ for $30 \mathrm{~min}$, from $180^{\circ} \mathrm{C}$ to 230 ${ }^{\circ} \mathrm{C}$ at $20^{\circ} \mathrm{C} \mathrm{min}^{-1}$, held at $230{ }^{\circ} \mathrm{C}$ for $16 \mathrm{~min}$, from $230^{\circ} \mathrm{C}$ to $250^{\circ} \mathrm{C}$ at $20^{\circ} \mathrm{C} \mathrm{min}^{-1}$, held at $250^{\circ} \mathrm{C}$ for $13 \mathrm{~min}$, from $250{ }^{\circ} \mathrm{C}$ to $280^{\circ} \mathrm{C}$ at $20^{\circ} \mathrm{C} \mathrm{min}^{-1}$, held at $280^{\circ} \mathrm{C}$ for $20 \mathrm{~min}$. In order to determine the analytes, a mass spectrometer (Agilent Technologies 5975C, upgraded with a triple-axis detector, Palo Alto, CA, USA) was used. The temperature of the ion source was $230^{\circ} \mathrm{C}$, the auxiliary temperature was $280^{\circ} \mathrm{C}$ and the quadrupole temperature was $150^{\circ} \mathrm{C}$. For qualitative determination, the retention time and 
mass spectrum in the SIM were used. For each active substance, one target and two qualifier ions, presented in Table 2, were used. The calibration was performed to matrix match standards.

\section{4. VALIDATION OF METHODS}

\section{LOQ and linearity}

The linearity was verified using the matrix match standards (two repetitions for one concentration level, four to six concentration levels for the calibration curve). The linearity and range were determined by linear regression, using the $\mathrm{F}$ test.

LOQs were estimated from the chromatograms of matrix match standards. LOQs were chosen at a minimum of $\mathrm{S} / \mathrm{N}=10$.

MRLs for environmental pesticide residues are set in Regulation (EC) 396/2005. Where the MRLs are set at the LOQ determined using the analytical method (this LOQ was gathered by different laboratories) in the Regulation an ${ }^{\star}$ is added to mark this fact. Therefore, in cases where MRLs were marked with an ${ }^{\star}$, our LOQs were set at those MRLs.

\section{Precision}

Blank pollen was bought in store and analysed to prove that it contains no pesticide residues. For the determination of precision (ISO 5725), i.e. repeatability and reproducibility, the extracts of spiked blank pollen were analysed at LOQ. Within a period of 10 days, two parallel extracts were prepared each day for each concentration level. Each one was injected once. Then the standard deviation of the repeatability of the level and the standard deviation of reproducibility of the level were both calculated.

Uncertainty of repeatability and uncertainty of reproducibility

The uncertainty of repeatability and the uncertainty of reproducibility were calculated by multiplying the standard deviation of repeatability and the standard deviation of reproducibility by the Student's $t$ factor, for nine degrees of freedom and a $95 \%$ confidence level $\left(t_{95 ; 9}\right.$ $=2.262$ ).

$$
\mathrm{U}_{\mathrm{r}}=\mathrm{t}_{95 ; 9} \mathrm{xs}_{\mathrm{r}} ; \mathrm{U}_{\mathrm{R}}=\mathrm{t}_{95 ; 9} \mathrm{Xs}_{\mathrm{R}}
$$

The measurement uncertainty for PPP residues should be $50 \%$, as proposed in SANTE/11813/2017. When validating, analysts must prove that their measurement uncertainty is below or equal to the proposed measurement uncertainty.

\section{Accuracy}

The accuracy was verified by checking the recoveries. The average of the recoveries from the tests for precision (10 days, 2 parallel samples each day) was calculated. According to the requirements for method validation procedures (SANTE/11813/2017), acceptable mean recoveries are those within the range of $70 \%$ to $120 \%$, with an associated repeatability of RSDr $\leq 20 \%$.

According to the guidelines for single-laboratory validation (Alder et al. 2000), acceptable mean recoveries are as follows:

- at level $>0.01 \mathrm{mg} \mathrm{kg}^{-1} \leq 0.1 \mathrm{mg} \mathrm{kg}^{-1}$, acceptable mean recoveries are those within the range of $70 \%$ to $120 \%$, with an associated repeatability RSDr $\leq 20 \%$ and

- at level $>0.001 \mathrm{mg} \mathrm{kg}^{-1} \leq 0.01 \mathrm{mg} \mathrm{kg}^{-1}$, acceptable mean recoveries are those within the range of $60 \%$ to 120 $\%$, with an associated repeatability RSDr $\leq 30 \%$.

\section{5. CONSUMER RISK ASSESSMENT}

Long-term exposure was calculated using the EFSA PRIMo model revision 3.1, accessible online at https:// www.efsa.europa.eu/en/applications/pesticides/tools. Chronic consumer exposure was expressed in \% of the ADI. The acceptable limit for long-term exposure is 100 $\%$ of the ADI.

\section{6. SAMPLING}

A total of 30 bee pollen samples (none of them beebread) were collected in May and June 2020 from Slovenian beekeepers that produce apiculture products sold on the market. Samples were gathered from all 12 statistical regions in Slovenia. The sampling distribution is presented in Table 1. All samples originated from conventional production.

\section{RESULTS AND DISCUSSION}

\section{1. COMPARISON OF QUECHERS METHOD WITH OUR METHOD}

In the original QuEChERS method, $10 \mathrm{ml}$ of acetonitrile was added to $10 \mathrm{~g}$ of the sample (Anastassiades et al.; 2003). In our method this ratio was different: 80 $\mathrm{ml}$ of acetonitrile was added to $10 \mathrm{~g}$ of the sample. The reason for increasing the solvent volume was that when we tested the addition of $10 \mathrm{ml}$ of acetonitrile to $10 \mathrm{~g}$ of pollen, the recoveries were $20-30 \%$ lower. 
Table 1: Number of pollen samples collected from different statistical regions in Slovenia in 2020

\begin{tabular}{lc}
\hline \multicolumn{1}{c}{ Statistical region } & Number of samples \\
\hline Gorenjska & 2 \\
Goriška & 2 \\
Jugovzhodna Slovenija & 1 \\
Koroška & 2 \\
Notranje kraška & 3 \\
Obalno kraška & 2 \\
Osrednja Slovenija & 7 \\
Podravska & 3 \\
Pomurska & 2 \\
Savinjska & 3 \\
Spodnje posavska & 1 \\
Zasavska & 2 \\
Sum & 30
\end{tabular}

The clean-up in our method was not conducted with dispersive SPE as in the original QuEChERS method (Anastassiades et al.; 2003, Lehotay; 2007), but with Ultra $24003 \mathrm{ml}$ SPE columns.

In the QuEChERS method, aliquots of extracts were cleaned-up, while in our method, the transference of the extracts was quantitative.

\section{2. VALIDATION OF METHOD}

LOQ and linearity

The linear model is valid for all active substances presented in Table 2. Linearity was proven in the range of $0.01 \mathrm{mg} \mathrm{kg}^{-1}$ to $0.15 \mathrm{mg} \mathrm{kg}^{-1}$ for six active substances, in the range of $0.05 \mathrm{mg} \mathrm{kg}^{-1}$ to $0.12 \mathrm{mg} \mathrm{kg}^{-1}$ for one active substance and in the range of $0.05 \mathrm{mg} \mathrm{kg}^{-1}$ to $0.15 \mathrm{mg} \mathrm{kg}^{-1}$ for 42 active substances. $\mathrm{R}^{2}$ ranged from 0.974 to 0.996 .

The LOQs are presented in Table 2. Six active substances have an LOQ of $0.01 \mathrm{mg} \mathrm{kg}^{-1}$ and 43 of them 0.05 $\mathrm{mg} \mathrm{kg}{ }^{-1}$. The LOQs are equal to MRLs set in Regulation (EC) $396 / 2005$.

\section{Accuracy}

The results for the recoveries are given in Table 2. The recoveries at LOQs for the active substances scanned with GC-MS are in the range of $73.0 \%$ to $93.4 \%$, with RSDs of $5.6 \%$ to $17.7 \%$. More precisely, the recoveries at LOQs of $0.01 \mathrm{mg} \mathrm{kg}^{-1}$ are within the range of $75.4 \%$ to $93.4 \%$ with RSDs of $9.3 \%$ to $17.7 \%$ and the recoveries at LOQs of $0.05 \mathrm{mg} \mathrm{kg}^{-1}$ are within the range of $73.0 \%$ to $88.2 \%$ with RSDs of $5.6 \%$ to $15.9 \%$.

All recoveries and RSDs are within the required ranges from the literature (Alder et al., 2000; SANTE/11813/2017).

Uncertainty of repeatability and uncertainty of reproducibility

The uncertainty of repeatability and uncertainty of reproducibility were determined at contents equal to the LOQs. The results are presented in Table 2. Uncertainty of repeatability ranged from $0.001 \mathrm{mg} \mathrm{kg}^{-1}$ to $0.013 \mathrm{mg}$ $\mathrm{kg}^{-1}$, which is $10.0 \%$ to $30.0 \%$ of LOQ and uncertainty of reproducibility ranged from $0.002 \mathrm{mg} \mathrm{kg}^{-1}$ to $0.015 \mathrm{mg}$ $\mathrm{kg}^{-1}$, which is $12.0 \%$ to $30.0 \%$ of LOQ. 


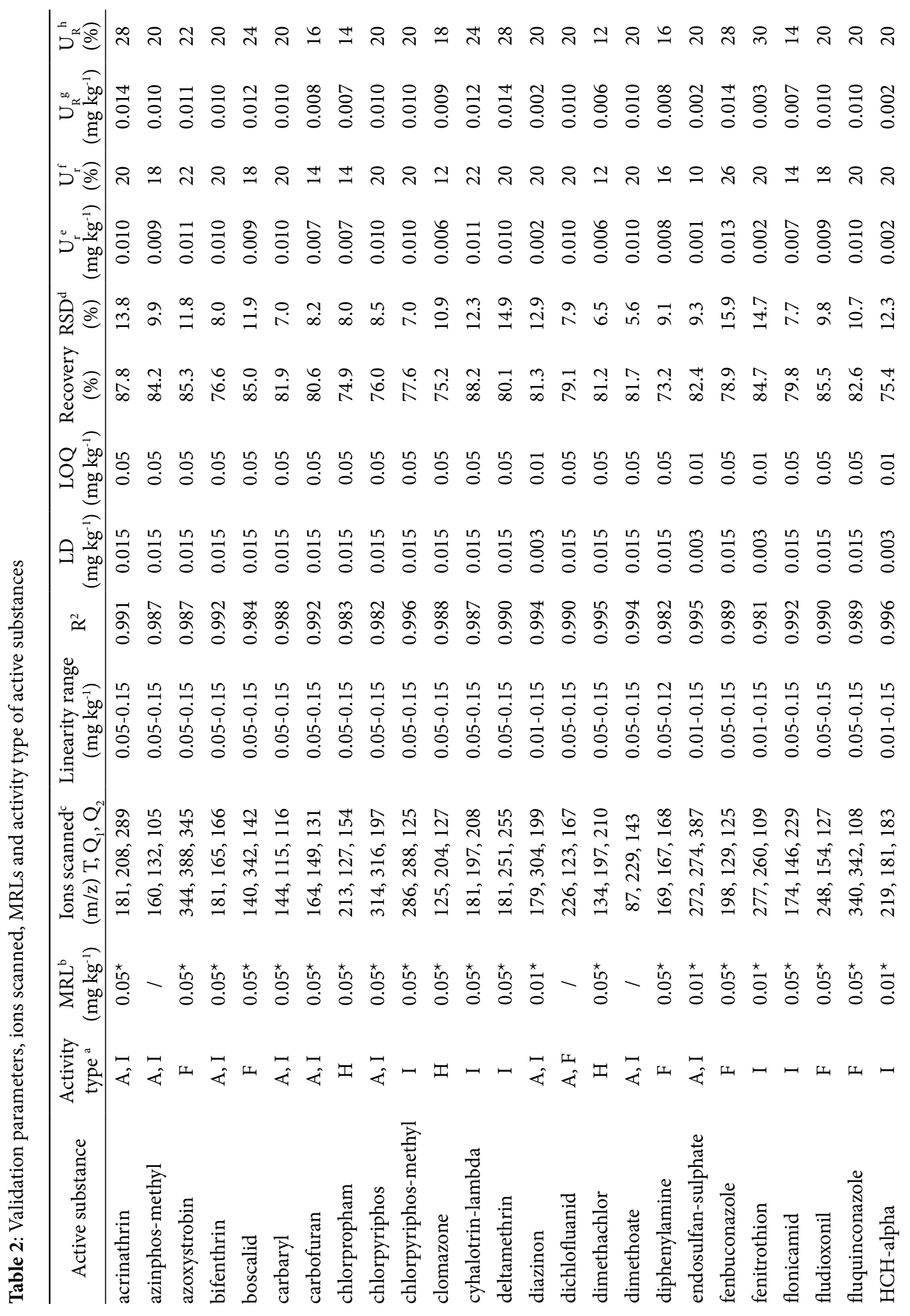




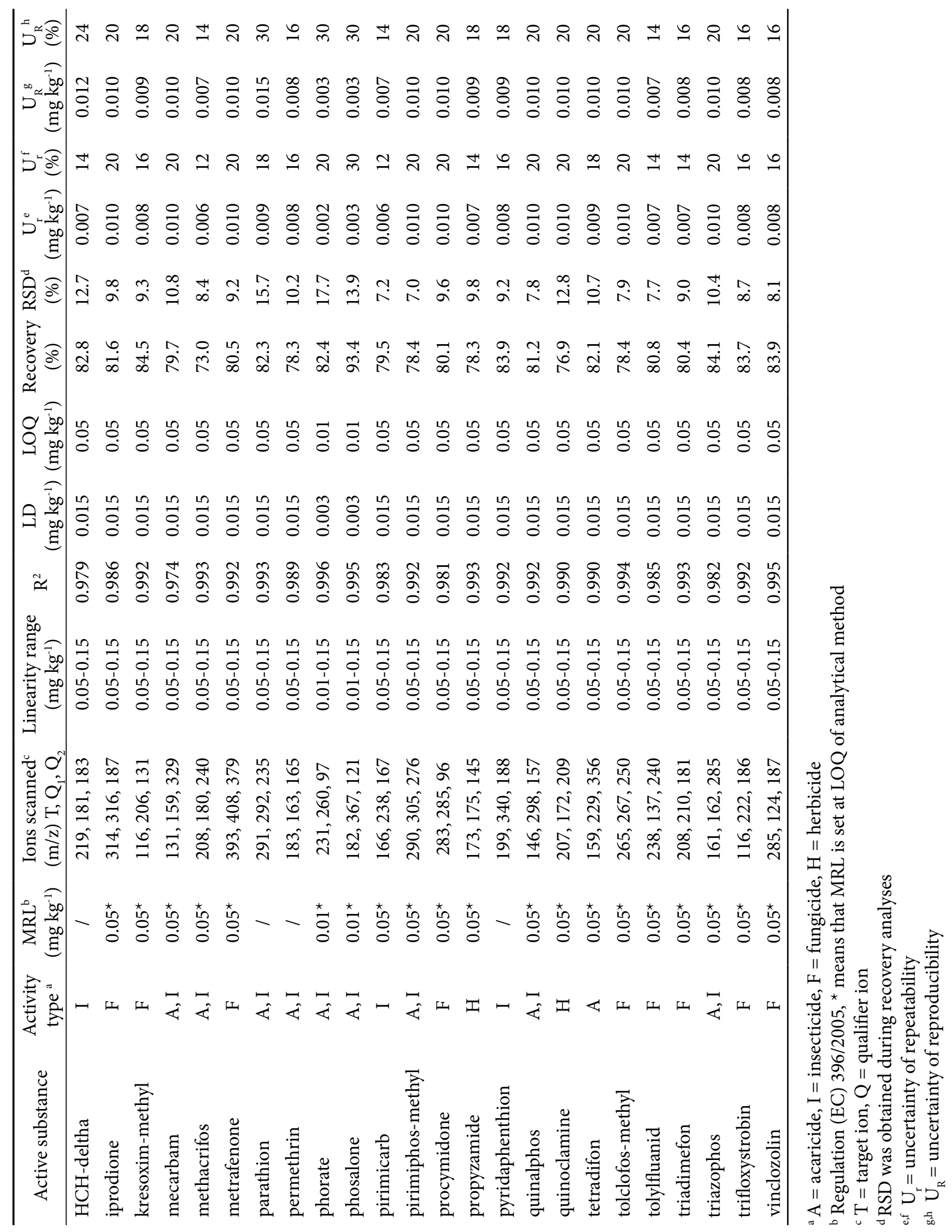




\section{3. SURVEY OF PESTICIDE RESIDUES IN BEE POLLEN SAMPLES}

The Ministry of Agriculture, Forestry and Food reported that in Slovenia in 2020, 582 PPPs, containing 239 active substances, are authorised for use on different agricultural products. The Statistical Office announced that in 2018, 1,172 tons of active substances were sold in Slovenia, where we have 476,000 hectares of cultivated agricultural area. This suggests broad use of PPPs among farmers. Since bees collect pollen not only on flowers, acacia, spruce, sage, lime and chestnut but also on agricultural products treated with PPPs, such as oilseed rape, fruits, etc., we wanted to research if these kinds of pesticide residues are found in bee pollen. We were searching for authorised (33\% of active substances sought) and non-authorised active substances in Slovenia, to cover the possible misuse of PPPs.

Of the 30 bee pollen samples analysed, only one contained one active substance: azoxystrobin, with a concentration of $<0.05 \mathrm{mg} \mathrm{kg}^{-1}$. This means that in 96.7 $\%$ of all samples analysed, no pesticide residues were detected. The MRL for azoxystrobin in pollen is $0.05 \mathrm{mg}$ $\mathrm{kg}^{-1}$ and it was not exceeded. In Slovenia, azoxystrobin is authorised as a fungicide for use on oilseed rape, vine and ornamentals (among others) in 14 different PPPs. These are the plants on which bees collect pollen.

A consumer risk assessment was performed using the EFSA PRIMo model rev. 3.1, in which 36 national diets from EU countries are included. This model was used since Slovenia has not created a model of its own. The same model is used in the process of registration of PPPs in Slovenia. Since azoxystrobin was the only substance found and it was only found in one sample at a concentration of $<\mathrm{LOQ}$, the LOQ for this substance was used as the input value in PRIMo model. It was compared to the Acceptable Daily Intake (ADI) of azoxystrobin $(0.2 \mathrm{mg}$ $\left.(\mathrm{kg} \mathrm{bw})^{-1} \mathrm{~d}^{-1}\right)$. The calculations of chronic exposure for azoxystrobin showed that the highest was observed in the German diet for children. It represented $0.003 \%$ of ADI. Since no Acute Reference Dose was set for azoxystrobin, no acute exposure was calculated. Based on these calculations, the conclusion was that the analysed bee pollen samples are of no cause for concern for consumers.

Our results were compared with the results from other scientific papers. Azoxystrobin was found in the Estonian pollen by Raimets et al. (2020) in $3.4 \%$ of all samples analysed up to a concentration of $0.04 \mathrm{mg} \mathrm{kg}$ 1. Tosi et al. (2018) wrote that azoxystrobin was found in $2.9 \%$ of the Italian pollen samples analysed, with a maximum concentration of $0.054 \mathrm{mg} \mathrm{kg}^{-1}$. Vázquez et al. (2015) reported that azoxystrobin was found in a concentration of up to $0.235 \mathrm{mg} \mathrm{kg}^{-1}$ in the Spanish pollen.
Azoxystrobin was found in $3.3 \%$ of the Slovenian pollen samples analysed, which is comparable to Estonia and Italy. The concentration of azoxystrobin found in Slovenia is comparable to that found in Estonia and Italy, but much lower than in Spain.

Other active substances analysed in our laboratory, namely acrinathrin, bifenthrin, boscalid, carbaryl, carbofuran, chlorpyrifos, clomazone, dimethoate, fenitrothion, fludioxonil, iprodione, lambda-cyhalothrin, permethrin, trifloxystrobin and vinclozoline, were not detected in Slovenian pollen, but were found in samples analysed in Estonia, France, Greece, Italy, Spain and the United Kingdom.

All active substances sought by our laboratory and positively identified in Europe were measured up to concentrations higher than our LDs. The exception is carbofuran, which was found at a concentration 10-times lower than our LD. Literature results for these active substances are presented in Table 3.

\section{CONCLUSIONS}

In our research, a method for determining pesticide residues originating from the environment in pollen was introduced and validated. The limit of detection was $0.003 \mathrm{mg} \mathrm{kg}^{-1}$ for 6 active substances and $0.01 \mathrm{mg} \mathrm{kg}^{-1}$ for 43 active substances. The limit of quantification was $0.01 \mathrm{mg} \mathrm{kg}^{-1}$ for 6 active substances and $0.05 \mathrm{mg} \mathrm{kg}^{-1}$ for 43 active substances. The calibration curves gave a linear response with $R^{2} 0.974$ to 0.996 . The recoveries ranged from $73.0 \%$ to $93.4 \%$ with RSDs from $5.6 \%$ to $17.7 \%$. The measurement uncertainty of repeatability ranged from 10 to $30 \%$ and the measurement uncertainty of reproducibility from 12 to $30 \%$. The method was found to be fit for purpose of measuring possible breaches of MRL for 49 active substances.

The method was used to analyse 30 bee pollen samples gathered from Slovenian beekeepers, all from conventional production. A total of 49 active substances were sought, but only the fungicide azoxystrobin was found in only one of these samples. In $96.7 \%$ of the samples analysed, the active substances sought were not detected. A risk assessment revealed that the Slovenian bee pollen samples are no cause for concern for consumers.

\section{ACKNOWLEDGEMENTS}

The author expresses her thanks to Mojca Trček for her help with the preparation of the extracts. The author acknowledges the financial support of the Slovenian Research Agency (research core funding No. P4-0133). 
Table 3: Literature results for active substances sought, but not found in our laboratory

\begin{tabular}{|c|c|c|c|c|c|}
\hline $\begin{array}{c}\text { Active } \\
\text { substance }\end{array}$ & $\begin{array}{l}\text { Limit of } \\
\text { detection } \\
\left(\mathrm{mg} \mathrm{kg}^{-1}\right)\end{array}$ & $\begin{array}{c}\text { Max } \\
\text { content } \\
\left(\mathrm{mg} \mathrm{kg}^{-1}\right)\end{array}$ & $\begin{array}{c}\text { Ratio of } \\
\text { positive } \\
\text { samples (\%) }\end{array}$ & Country of origin & Reference \\
\hline acrinathrin & not reported & 0.458 & 20.0 & Spain & Calatayud-Vernich et al., 2018 \\
\hline acrinathrin & 0.015 & 0.055 & not reported & Spain & Vázquez et al., 2015 \\
\hline bifenthrin & 0.015 & 0.015 & not reported & Spain & Vázquez et al., 2015 \\
\hline boscalid & 0.0025 & 0.058 & 0.7 & Italy & Tosi et al., 2018 \\
\hline boscalid & 0.00012 & 0.021 & 52.0 & United Kingdom & David et al., 2016 \\
\hline boscalid & 0.0015 & 0.03 & not reported & Spain & Vázquez et al., 2015 \\
\hline carbaryl & 0.0007 & 0.015 & 8.0 & France & Wiest et al., 2011 \\
\hline carbaryl & 0.00025 & 0.001 & 0.2 & Italy & Tosi et al., 2018 \\
\hline carbofuran & 0.0004 & 0.002 & 2.0 & France & Wiest et al., 2011 \\
\hline chlorpyrifos & not reported & 0.05 & 14.0 & Spain & Hakme et al., 2017 \\
\hline chlorpyrifos & 0.001 & 0.3982 & not reported & Spain & García-Valcárcel et al., 2019 \\
\hline chlorpyrifos & not reported & 0.1 & 31.1 & Spain & Calatayud-Vernich et al., 2018 \\
\hline chlorpyrifos & 0.0015 & 0.07 & not reported & Spain & Vázquez et al., 2015 \\
\hline chlorpyrifos & 0.008 & 0.14 & 4.0 & France & Wiest et al., 2011 \\
\hline chlorpyrifos & 0.0032 & 0.046 & not reported & Greece & Kasiotis et al., 2014 \\
\hline chlorpyrifos & 0.001 & 0.179 & 30.3 & Italy & Tosi et al., 2018 \\
\hline clomazone & not reported & 0.02 & 5.0 & Spain & Hakme et al., 2017 \\
\hline dimethoate & not reported & 0.042 & 20.7 & Estonia & Raimets et al., 2020 \\
\hline dimethoate & 0.0015 & 0.015 & not reported & Spain & Vázquez et al., 2015 \\
\hline dimethoate & not reported & 0.022 & 8.9 & Spain & Calatayud-Vernich et al., 2018 \\
\hline dimethoate & 0.00025 & 0.163 & 7.9 & Italy & Tosi et al., 2018 \\
\hline dimethoate & 0.0028 & 0.1445 & not reported & Greece & Kasiotis et al., 2014 \\
\hline dimethoate & 0.0091 & 0.0182 & 1.0 & France & Wiest et al., 2011 \\
\hline fenithrothion & not reported & 0.014 & 2.2 & Spain & Calatayud-Vernich et al., 2018 \\
\hline fludioxonil & 0.0015 & 0.033 & not reported & Spain & Vázquez et al., 2015 \\
\hline iprodione & 0.0156 & 0.0195 & 1.0 & France & Wiest et al., 2011 \\
\hline $\begin{array}{l}\text { lambda- } \\
\text { cyhalothrin }\end{array}$ & not reported & 0.077 & 17.2 & Estonia & Raimets et al., 2020 \\
\hline permethrin & not reported & 0.034 & 5.0 & Spain & Hakme et al., 2017 \\
\hline permethrin & 0.0015 & 0.0035 & not reported & Spain & Vázquez et al., 2015 \\
\hline trifloxystrobin & 0.0086 & 0.058 & not reported & Greece & Kasiotis et al., 2014 \\
\hline trifloxystrobin & 0.00024 & 0.01 & 40.0 & United Kingdom & David et al., 2016 \\
\hline trifloxystrobin & 0.00025 & 0.046 & 5.6 & Italy & Tosi et al., 2018 \\
\hline trifloxystrobin & 0.0015 & 0.0154 & not reported & Spain & Vázquez et al., 2015 \\
\hline vinclozoline & 0.0015 & 0.07 & 2.0 & France & Wiest et al., 2011 \\
\hline
\end{tabular}




\section{REFERENCES}

Alder L., Hill A., Holland P.T., Lantos J., Lee S.M., MacNeil J.D., O'Rangers J., van Zoonen P., Ambrus A. (2000). Guidelines for single-laboratory validation of analytical methods for trace-level concentrations of organic chemicals, Principles and practices of method validation (ed.: A. Fajgelj, A. Ambrus). The Royal Society of Chemistry, pp. $179-252$.

Anastassiades M., Lehotay S. J., Štajnbaher D., Schenck F. J. (2003). Fast and easy multiresidue method employing acetonitrile extraction/partitioning and »dispersive solidphase extraction " for the determination of pesticide residues in produce. Journal of AOAC International, 86, 412431. https://doi.org/10.1093/jaoac/86.2.412

Cabrera de Oliveira R. C., Queiroz S. C. do N., da Luz C. F. P., Porto R. S., Rath S. (2016). Bee pollen as a bioindicator of environmental pesticide contamination. Chemosphere, 163,525-534. https://doi.org/10.1016/j.chemosphere.2016.08.022

Calatayud-Vernich P., Calatayud F., Simó E., Picó Y. (2018). Pesticide residues in honey bees, pollen and beeswax: Assessing beehive exposure. Environmental Pollution, 241, 106-114. https://doi.org/10.1016/j.envpol.2018.05.062

Crenna E., Jolliet O., Collina E., Sala S., Fantke P. (2020). Characterizing honey bee exposure and effects from pesticides for chemical prioritization and life cycle assessment. Environment International, 138, 105642. https://doi. org/10.1016/j.envint.2020.105642

David A., Botías C., Abdul-sada A., Nicholls E., Rotheray E. L., Hill E. M., Goulson D. (2016). Widespread contamination of wildflower and bee-collected pollen with complex mixtures of neonicotinoids and fungicides commonly applied to crops. Environment International, 88, 169-178. https:// doi.org/10.1016/j.envint.2015.12.011

Eckert J.E. (1933). The flight range of the honeybee. Journal of Agricultural Research, 47, 257-285.

García-Valcárcel A. I., Martínez-Ferrer M. T., Campos-Rivela J. M., Guil M. D. H. (2019). Analysis of pesticide residues in honeybee $\check{Z}$ (Apis mellifera L.) and in corbicular pollen. Exposure in citrus orchard with an integrated pest management system. Talanta, 204, 153-162. https://doi. org/10.1016/j.talanta.2019.05.106

Hakme E., Lozano A., Gómez-Ramos M. M., Hernando M. D., Fernández-Alba A. R. (2017). Non-target evaluation of contaminants in honey bees and pollen samples by gas chromatography time-of-flight mass spectrometry. Chemosphere, 184, 1310-1319. https://doi.org/10.1016/j.chemosphere.2017.06.089.

ISO 5725. (1994). Accuracy (trueness and precision) of measurement methods and results - Part2: Basic method for the determination of repeatability and reproducibility of a standard measurement method, pp. 1-42.

Kasiotis K. M., Anagnostopoulos C., Anastasiadou P., Machera K. (2014). Pesticide residues in honeybees, honey and bee pollen by LC-MS/MS screening: Reported death incidents in honeybees. Sciience of the Total Environment, 485-486, 633-642. https://doi.org/10.1016/j.scitotenv.2014.03.042

Lehotay S. J. (2007). Determination of pesticide residues in foods by acetonitrile extraction and partitioning with magnesium sulfate: collaborative study. Journal of AOAC International, 90, 485-520. https://doi.org/10.1093/jaoac/90.2.485

Li Q.-Q., Wang K., Marcucci M. C., Sawaya A. C. H. F., Hu L., Xue X.-F., Wu L.-M. (2018). Nutrient-rich bee pollen: A treasure trove of active natural metabolites. Journal of Functional Foods, 49, 472-484. https://doi.org/10.1016/j. jff.2018.09.008

Li Y., Kelley R. A., Anderson T. D., Lydy M. J. (2015). Development and comparison of two multi-residue methods for the analysis of select pesticides in honey bees, pollen, and wax by gas chromatography-quadropole mass spectrometry. Talanta, 140, 81-87. https://doi.org/10.1016/j.talanta.2015.03.031

Lozano A., Rajski Ł., Uclés S., Belmonte-Valles N., Mezcua M., Fernández-Alba A. R. (2014). Evaluation of zirconium dioxide-based sorbents to decrease the matrix effect in avocado and almond multiresidue pesticide analysis followed by gas chromatography tandem mass spectrometry. Talanta, 118, 68-83. https://doi.org/10.1016/j.talanta.2013.09.053

Mullin C. A., Frazier M., Frazier J. L., Ashcraft S., Simonds R., vanEngelsdorp D., Pettis J. S. (2010). High levels of miticides and agrochemicals in North American Apiaries: implications for honey bee health. PLOS one, 5, e9754. https:// doi.org/10.1371/journal.pone.0009754

Nakajima Y., Tsuruma K., Shimazawa M., Mishima S., Hara H. (2009). Comparison of bee products based on assays of antioxidant capacities. BioMed Central, 9, 4. https://doi. org/10.1186/1472-6882-9-4

Raimets R., Bontšutšnaja A., Bartkevics V., Pugajeva I., Kaart T., Puusepp L., Pihlik P., Keres I., Viinalass H., Mänd M., Karise R. (2020). Pesticide residues in beehive matrices are dependent on collection time and matrix type but independent of proportion of foraged oilseed rape and agricultural land in foraging territory. Chemosphere, 238, 124555. https://doi.org/10.1016/j.chemosphere.2019.124555

Salles J., Cardinault N., Patrae V., Berry A., Giraudet C., Collin M.-L., Chanet A., Tagliaferri C., Denis P., Pouyet C., Boirie Y., Walrand S. (2014). Bee pollen improves muscle protein and energy metabolism in malnourished old rats through interfering with the Mtor signaling pathway and mitochondrial activity. Nutrients, 6, 5500-5516. https://doi. org/10.3390/nu6125500

SANTE/11813/2017. Guidance document on analytical quality control and method validation procedures for pesticide residues analysis in food and feed. DG SANTE, European Comission, 2017.

Stenerson K. K, (2018). Analysis of pesticides in turmeric powder by LC-MS/MS and GC-MS/MS after cleanup with a novel dual-layer SPE cartridge. Supelco Analytical Products, Analytix reporter, 1, 2018.

Thakur M., Nanda V. (2020). Composition and functionality of bee pollen: A review. Trends in Food Science \& Technology, 98, 82-106. https://doi.org/10.1016/j.tifs.2020.02.001

Tosi S., Costa C., Vesco U., Quaglia G., Guido G. (2018). A 3-year survey of Italian honey bee-collected pollen reveals widespread contamination by agricultural pesticides. Science of the Total Environment, 615, 208-218. https://doi. org/10.1016/j.scitotenv.2017.09.226

Vázquez P. P., Lozano A., Uclés S., Ramos M. M. G., Fernández- 
Alba A. R. (2015). A sensitive and efficient method for routine pesticide multiresidue analysis in bee pollen samples using gas and liquid chromatography coupled to tandem mass spectrometry. Journal of Chromatography A, 1426, 161-173. https://doi.org/10.1016/j.chroma.2015.11.081

Wang P.-C., Lee R.-J., Chen C.-Y., Chou C.-C., Lee M.-R. (2012). Determination of cyromazine and melamine in chiken eggs using quick, easy, cheap, effective, rugged and safe (QuEChERS) extraction coupled with liquid chroma- tography-tandem mass spectrometry. Analytica Chimica Acta, 752, 78-86. https://doi.org/10.1016/j.aca.2012.09.029

Wiest L., Buleté A., Giroud B., Fratta C., Amic S., Lambert O., Pouliquen H., Arnaudguilhem C. (2011). Multi-residue analysis of 80 environmental contaminants in honeys, honeybees and pollens by one extractuion procedure followed by liquid and gas chromatography coupled with mass spectrometric detection. Journal of Chromatography A, 1218, 5743-5756. https://doi.org/10.1016/j.chroma.2011.06.079 